\title{
Aggregations of wild Atlantic Bluefin Tuna (Thunnus thynnus L.) at Mediterranean offshore fish farm sites: Environmental and management considerations
}

\author{
Pablo Arechavala-Lopez ${ }^{\mathrm{a}, *}$, Joseph A. Borg ${ }^{\mathrm{b}}$, Tanja Šegvić-Bubićc ${ }^{\mathrm{c}}$, Paolo Tomassetti ${ }^{\mathrm{d}}$, \\ Aytaç Özgül ${ }^{\mathrm{e}}$, Pablo Sanchez-Jerez ${ }^{\mathrm{a}}$ \\ a Department of Marine Science and Applied Biology, University of Alicante, PO Box 99, 03080 Alicante, Spain \\ ${ }^{\mathrm{b}}$ Department of Biology, Faculty of Science, University of Malta, Msida MSD2080, Malta \\ ' Institute of Oceanography and Fisheries, Setaliste I. Mestrovica 63, 21000 Split, Croatia \\ d ISPRA, Italian National Institute for Environmental Protection and Research, via di Castel Romano 100, Roma, Italy \\ ${ }^{\text {e }}$ Ege University, Faculty of Fisheries, Bornova, Izmir 35100, Izmir, Turkey
}

\section{A R T I C L E I N F O}

\section{Article history:}

Received 8 April 2014

Received in revised form 3 November 2014

Accepted 11 November 2014

Handling Editor B. Morales-Nin

Available online 24 December 2014

\section{Keywords:}

Large pelagic fin-fish

Aquaculture

Fisheries

Interactions

Ecological risks

Management

\begin{abstract}
A B S T R A C $T$
In recent years, Atlantic Bluefin Tuna (Thunnus thynnus) is being observed to increasingly and more frequently aggregate around Mediterranean offshore fish farms. In the present work, potential interactions between aggregations of this important pelagic species and offshore fish farms and local fisheries were assessed through a questionnaire survey aimed at fish farmers, divers and stakeholders in the Mediterranean. Since the interactions may have implications for aquaculture and marine ecology, enhanced management strategies for the conservation of endangered Mediterranean stocks of Atlantic Bluefin tuna, as well as for sustainable development of aquaculture and fishery activities are discussed.
\end{abstract}

(C) 2014 Elsevier B.V. All rights reserved.

\section{Introduction}

Marine wild fish are attracted to a wide variety of natural and artificial structures in coastal areas, commonly termed fish aggregation devices (FADs; Dempster and Tanquet, 2004). Fishermen have been familiar with the phenomenon of large aggregations of wild fish around FADs for centuries and have used such structures extensively to attract commercially and recreationally important pelagic fish in different parts of the world (Kingsford, 1999). The floating structures of coastal fish farms themselves act as FADs, providing shelter and an abundance of food for a large variety of pelagic and demersal fish species that are of both ecological and economic importance. In the Mediterranean, several studies have reported high abundances of farm-aggregated wild species, with around 40 different species being reported (see review by Sanchez-Jerez et al., 2011). The most commonly recorded families observed aggregated

\footnotetext{
* Corresponding author. Tel.: +34 965903473.

E-mail address: pablo.arechavala@ua.es (P. Arechavala-Lopez).
}

around offshore fish farms are Clupeidae, Sparidae, Mugilidae and Carangidae, which use trophic resources associated with fish farms, such as surplus food pellets or particulate organic matter. However, the abundance and assemblage composition of such aggregations vary significantly across different geographical areas, farms and seasons.

Assemblages of small wild fish aggregated in large numbers around fish farms also attract larger predatory species, due to the increased foraging opportunities (Sanchez-Jerez et al., 2011). For example, it is common to observe large shoals of bluefish (Pomatomus saltatrix) beneath fish cages, which not only feed on the small pelagic fish (e.g. Sardinella aurita, Trachurus mediterraneus, Boops boops) present in the vicinity of the farm, but also break into cages and attack the cultured fish, particularly sea bream (Sparus aurata) and sea bass (Dicentrarchus labrax) (Sanchez-Jerez et al., 2008; Arechavala-Lopez et al., 2014a). Thus, the interaction of bluefish with sea-cage aquaculture is considered a large problem in some parts of the Mediterranean Sea (Sanchez-Jerez et al., 2008). Other pelagic fishery species of commercial interest also occasionally aggregate at Mediterranean fish farms sites; these include 


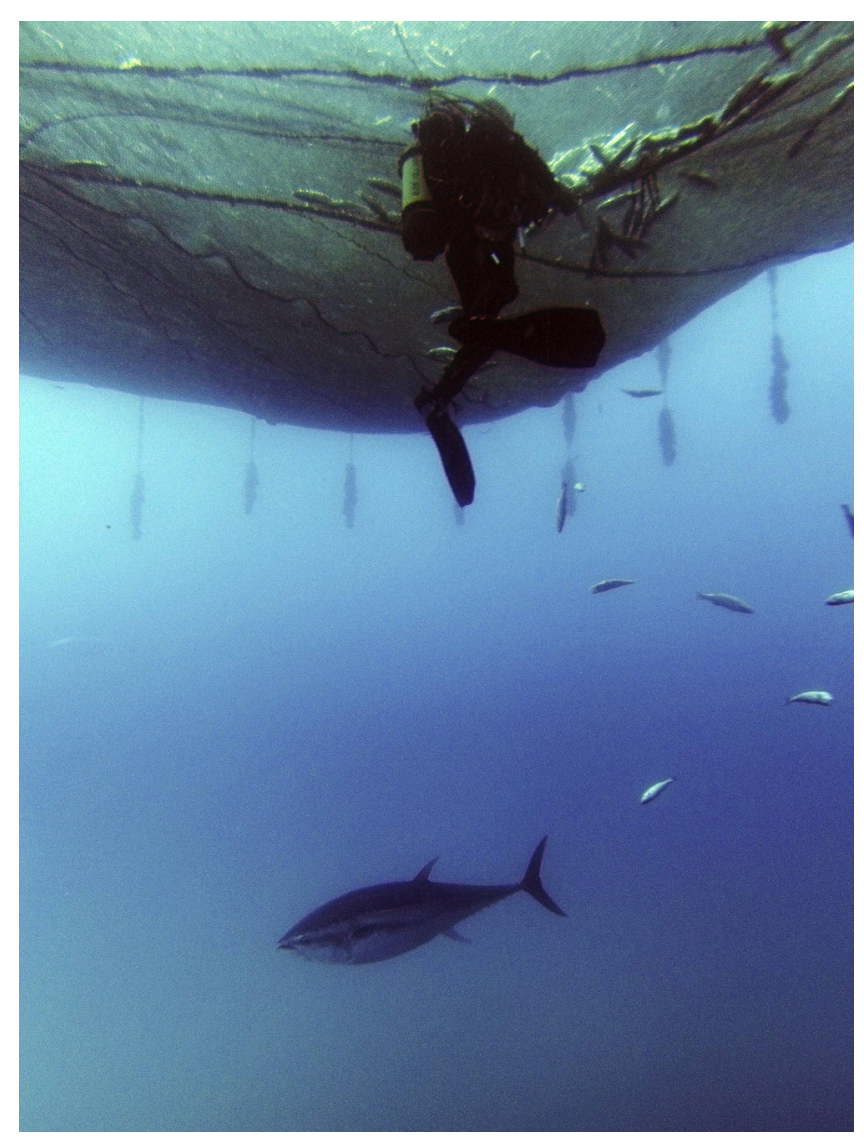

Fig. 1. Wild Atlantic Bluefin Tuna attracted to a Mediterranean fish farm feeding on discarded farmed fish beneath cages.

common dolphinfish (Coryphaena hippurus), greater amberjack (Seriola dumerili), Atlantic bonito (Sarda sarda) and chub mackerel (Scomber japonicus), among others (e.g. Sanchez-Jerez et al., 2011; Šegvić-Bubić et al., 2011; Bacher et al., 2012, 2013). Moreover, larger species such as swordfish (Xiphias gladius), which is enlisted in the IUCN Red List of Threatened Species (category: least concern; see http://www.iucnredlist.org), have also been sporadically observed in the vicinity of the farms (Arechavala-Lopez et al., 2014b). Other large marine pelagic fauna that have been recorded in the vicinity of fish farms include species of pelagic chondrichthyes, such as Blue Shark (Prionace glauca), which is listed as "vulnerable" (criterion A2cd +3cd) (e.g. Bacher et al., 2012), as well as some marine mammals whose populations are deemed "critically endangered" in the Mediterranean, such as Bottlenose Dolphin (Tursiops truncatus) (criterion A3bcd; C1), and Monk Seal (Monachus monachus) (criterion A2abc; C2a(i); E) (e.g. Güçlüsoy and Savas, 2003; Díaz-López and Bernal-Shirai, 2007; Piroddi et al., 2011).

Another large pelagic finfish that has been observed to aggregate around Mediterranean fish farm sites is Atlantic Bluefin Tuna (ABT; Thunnus thynnus) (Fig. 1). The presence of this species near offshore fish farms in the Mediterranean has increased during recent years, as reported by scientists (see Sanchez-Jerez et al., 2011), fish farmers and local fishermen from several parts of the Mediterranean basin. Atlantic Bluefin Tuna forms part of the pelagic ecosystem of the entire North Atlantic and its adjacent seas, primarily the Mediterranean Sea (Mather et al., 1995), and is the only large pelagic fish living permanently in temperate Atlantic waters (Bard et al., 1998; Fromentin and Fonteneau, 2001). Atlantic Bluefin Tuna is also a highly migratory species that seems to display seasonal migrations, and spawning site fidelity, in both the Mediterranean Sea and Gulf of Mexico, which constitute its two main spawn- ing areas (Block et al., 2005). The species is considered fully exploited' and its juveniles are submitted to heavy fishing pressure, particularly in the Mediterranean, which serves as the most important fishing ground for purse-seiner and long-liner fleets that harvest this species, but which is also captured using traps, handlines, bait boats and by sport fishermen (Ottolenghi, 2008). Since the 1990s, a capture-based aquaculture industry targeting ABT has developed in the Mediterranean. The starting stock of farmed ABT originates from catches made mostly by purse seiners that capture live individuals at different life cycle stages that are destined for farming purposes. As the activity is very lucrative, an increased catch effort has been noted during the last ten years or so (Relini, 2003; Fromentin and Powers, 2005; Ottolenghi, 2008). As a result of overexploitation of the species, ABT has recently been listed as an 'endangered' species (criterion A2bd, IUCN Red List), with the status of its wild populations being deemed 'critical' (ICCAT, 2012). However, very recently, the spawning stock of ABT showed clear signs of increased biomass, probably due to a substantial decrease in catch effort in the Eastern Atlantic and Mediterranean through implementation, by the International Commission for the Conservation of Atlantic Tunas, of a species management plan, entailing a limit (='quota') on harvests of the species, and of monitoring and enforcement controls on both the fishing and farming industries (ICCAT, 2012).

Coincident with ICATT's management regulations and the observed increase of ABT populations in the Mediterranean, an increase in the presence and residence time of ABT individuals attracted to the fish farm sites has been noted. Studies have reported the presence of $A B T$ beneath sea bream, sea bass and tuna cages throughout the Mediterranean (e.g. Fig. 1). It has been frequently observed that ABT aggregates around tuna farm cages in Croatia and Spain, mainly in spring, summer and autumn season (Šegvić-Bubić et al., 2011; Bacher et al., 2012). Akyol and Ertosluk (2010) recorded ABT at Turkish sea bream and sea bass fish farms. Dempster et al. (2002) and Fernandez-Jover et al. (2008) observed ABT at two sea bream and sea bass cages sited off the Spanish coast. Moreover, fish farmers and fishermen from various sites around the Mediterranean have reported an increase in the number and frequency of occurrence of aggregated $\mathrm{ABT}$ in the vicinity of tuna farms. Due to the high economic and ecological importance of this species, the main aims of the present opinion piece are to: (i) review existing knowledge of ABT aggregations around Mediterranean offshore fish farms; (ii) assess the magnitude of the interactions of aggregated ABT with fish farms and their potential effects across the Mediterranean Sea through questionnaires aimed at fish farmers, divers and stakeholders; (iii) discuss and suggest management strategies for the conservation of Mediterranean ABT stocks and the sustainable development of aquaculture and fishery activities.

\section{Material and methods}

The existing knowledge about ABT aggregations around Mediterranean fish farms was assessed through questionnaires sent to known stakeholders and aquaculture technicians (i.e. fish farmers and divers) from Spain, Italy, Croatia, Malta, Greece and Turkey. In these questionnaires the following information was gathered: (1) general information on the farm installations, including cultured species (tuna, bream, bass and/or meagre), year of commencement of the activity, number of cages and production, distance from the shore and water depth; (2) data on sightings of $\mathrm{ABT}$ around the farms, including presence and first sight recorded at farm, fish size range, density, frequency, seasonality and daily occurrence; (3) information on interactions of ABT with fish farms, wild fish and local fisheries; and on the potential consequences for both the fish farm production and ABT (see Table 1). The relation- 
Table 1

Results of questionnaires and interviews with Mediterranean fish farmers, divers and stakeholders, concerning ABT aggregations in the vicinity of fish farms.

\begin{tabular}{|c|c|c|c|c|c|c|c|c|c|c|c|c|c|c|c|c|c|c|c|}
\hline \multirow[t]{2}{*}{ Country } & \multirow{2}{*}{$\begin{array}{l}\text { Cultured } \\
\text { Sps. }\end{array}$} & \multirow{2}{*}{$\begin{array}{l}\text { Farm } \\
\text { starting } \\
\text { (year) }\end{array}$} & \multirow{2}{*}{$\begin{array}{l}\text { Farm } \\
\text { cages } \\
\text { (num.) }\end{array}$} & \multirow{2}{*}{$\begin{array}{l}\text { Total } \\
\text { produc- } \\
\text { tion } \\
\text { (t) }\end{array}$} & \multirow{2}{*}{$\begin{array}{l}\text { Shore } \\
\text { distance } \\
(\mathrm{km})\end{array}$} & \multirow{2}{*}{$\begin{array}{l}\text { Farm } \\
\text { depth } \\
\text { (m) }\end{array}$} & \multirow{2}{*}{$\begin{array}{l}\text { Presence } \\
\text { Tuna (Y, } \\
\text { N) }\end{array}$} & \multirow{2}{*}{$\begin{array}{l}\text { First } \\
\text { sight } \\
\text { (year) }\end{array}$} & \multirow{2}{*}{$\begin{array}{l}\text { Density } \\
\text { Tuna } \\
\text { (num.) }\end{array}$} & \multirow{2}{*}{$\begin{array}{l}\text { Range } \\
\text { size (kg) }\end{array}$} & \multirow{2}{*}{$\begin{array}{l}\text { Actual } \\
\text { fre- } \\
\text { quency } \\
(\mathrm{H}, \mathrm{M}, \mathrm{L})\end{array}$} & \multirow{2}{*}{$\begin{array}{l}\text { Seasonal } \\
\text { presence } \\
\text { (months) }\end{array}$} & \multirow{2}{*}{$\begin{array}{l}\text { Daily } \\
\text { occur- } \\
\text { rence } \\
\text { (hours) }\end{array}$} & \multicolumn{5}{|c|}{ Interactions $(\mathrm{Y} / \mathrm{N})$} & \multirow{2}{*}{$\begin{array}{l}\text { Economic } \\
\text { losses } \\
\text { for } \\
\text { farmers }\end{array}$} \\
\hline & & & & & & & & & & & & & & F. Fish & Struct. & Divers & Fauna & Fisheries & \\
\hline \multirow[t]{6}{*}{ Spain } & Bs & - & - & - & $4-5$ & 39 & Yes & - & $15-20$ & $80-300$ & High & Summer, Autumn & $24 \mathrm{~h}$ & Yes & Yes & Yes & Yes & No & Yes \\
\hline & Bs & 2000 & 24 & 1000 & 0.9 & $35-45$ & Yes & 2002 & $5-6$ & $150-250$ & High & 4 seasons $(1-12)$ & $24 \mathrm{~h}$ & Yes & Yes & No & Yes & Yes & Yes \\
\hline & Bs & 2001 & 24 & & 3.5 & 40 & Yes & 2003 & $4-10$ & $>200$ & High & 4 seasons $(1-12)$ & $24 \mathrm{~h}$ & Yes & Yes & Yes & Yes & No & Yes \\
\hline & $\mathrm{Br}, \mathrm{Bs}$ & 2001 & 14 & 1300 & 3 & $30-40$ & Yes & 2011 & $<15$ & $50-250$ & High & 4 seasons $(1-12)$ & $24 \mathrm{~h}$ & Yes & No & Yes & Yes & No & Yes \\
\hline & $\mathrm{Br}, \mathrm{Bs}$ & 2001 & 36 & 1800 & 0.7 & $32-44$ & Yes & 2005 & $1-6$ & $150-200$ & High & 4 seasons $(1-12)$ & $24 \mathrm{~h}$ & Yes & No & Yes & Yes & No & Yes \\
\hline & $\mathrm{Br}$, Me & 2001 & 30 & 1250 & $3-4$ & $24-30$ & Yes & 2011 & $2-5$ & $40-200$ & High & 4 seasons $(1-12)$ & Morning/24h & No & No & Yes & Yes & No & No \\
\hline \multirow{3}{*}{ Italy } & $\mathrm{Br}$, Bs & 1995 & 21 & 700 & 0.2 & $17-26$ & Yes & 2001 & $1-3$ & $60-100$ & Medium & 4 seasons $(1-12)$ & $24 \mathrm{~h}$ & Yes & No & No & Yes & Yes & No \\
\hline & $\mathrm{Br}, \mathrm{Bs}$ & 2008 & 18 & 600 & 4 & $24-28$ & Yes & 2011 & $5-6$ & $200-300$ & Medium & 4 seasons $(2-11)$ & Morning/evening & Yes & No & Yes & No & No & No \\
\hline & $\mathrm{Br}$, Bs & 2000 & 12 & 400 & 1.7 & $22-26$ & Yes & 2001 & $<6$ & $100-200$ & Medium & 4 seasons $(1-12)$ & $24 \mathrm{~h}$ & No & No & No & No & No & No \\
\hline \multirow[t]{7}{*}{ Croatia } & $\mathrm{Br}, \mathrm{Bs}$ & 1990 & 68 & 1375 & 0.3 & $60-70$ & Yes & 2012 & $2-4$ & $100-150$ & Medium & Spring, Summer & Morning & No & No & Yes & No & No & No \\
\hline & $\mathrm{Br}, \mathrm{Bs}$ & 1993 & 40 & 600 & $<0.1$ & $20-40$ & Yes & 2001 & $3-10$ & $10-150$ & & Summer, Autumn & $24 \mathrm{~h}$ & No & No & No & Yes & Yes & Yes \\
\hline & $\mathrm{Br}, \mathrm{Bs}, \mathrm{Me}$ & 1984 & 58 & 1000 & $0.3-0.6$ & $30-60$ & Yes & 2002 & $<3$ & $50-300$ & Medium & Summer & $24 \mathrm{~h}$ & Yes & Yes & No & No & No & No \\
\hline & ${ }^{\#} \mathrm{Br}, \mathrm{Bs}, \mathrm{Me}$ & 1979-2006 & - & 4050 & 0.1 & $30-50$ & Yes & - & $3-5$ & $>100$ & High & Summer, Autumn & $24 \mathrm{~h}$ & Yes & Yes & Yes & Yes & No & Yes \\
\hline & $\mathrm{Tu}$ & 1996 & 12 & 500 & 0.5 & 65 & Yes & 1997 & $50-100$ & $10-300$ & High & Summer, Autumn & Morning & No & No & No & Yes & Yes & No \\
\hline & $\mathrm{Tu}$ & 2001 & 6 & 900 & 0.2 & 55 & Yes & 2001 & $10-200$ & $10-500$ & High & Spr, Sum, $(5-10)$ & Morning & No & No & No & Yes & Yes & No \\
\hline & $\mathrm{Tu}$ & 2007 & 18 & 1500 & 0.3 & 67 & Yes & 2010 & $50-100$ & $50-150$ & High & Summer, Autumn & Morning & No & No & No & Yes & Yes & No \\
\hline \multirow{3}{*}{ Malta } & $\mathrm{Tu}$ & 2000 & 9 & 2500 & 1 & 50 & Yes & 2002 & $100 \mathrm{~s}$ & $60-250$ & High & Summer (5-10) & Morning & Yes & Yes & No & Yes & Yes & Yes \\
\hline & Tu & 2001 & - & 1400 & 1 & $45-55$ & Yes & 2008 & - & $40-250$ & High & Summer $(7-8)$ & $24 \mathrm{~h}$ & No & No & Yes & Yes & Yes & No \\
\hline & $\mathrm{Tu}$ & 2002 & - & 1000 & 1 & 50 & Yes & 2010 & - & $60-200$ & Medium & Summer $(7-10)$ & Morning/24h & No & No & No & No & No & No \\
\hline Greece & $\mathrm{Br}, \mathrm{Bs}, \mathrm{Me}$ & 1987 & - & 2200 & 0.2 & $75-150$ & Yes & 1991 & $10-40$ & $50-250$ & High & 4 seasons $(1-12)$ & $24 \mathrm{~h}$ & No & No & Yes & Yes & Yes & No \\
\hline \multirow[t]{7}{*}{ Turkey } & $\mathrm{Tu}$ & 2003 & 12 & 1000 & 2 & $60-75$ & Yes & 2010 & $1-6$ & $50-150$ & High & 4 seasons $(1-12)$ & Morning & Yes & No & Yes & Yes & Yes & No \\
\hline & $\mathrm{Tu}$ & 2005 & 10 & 1000 & 1.3 & $60-75$ & Yes & 2008 & $5-6$ & 80 & High & 4 seasons $(1-12)$ & $24 \mathrm{~h}$ & Yes & No & Yes & Yes & No & No \\
\hline & Bs & 2005 & 28 & 2500 & 0.1 & $60-80$ & Yes & 2008 & $1-2$ & $100-120$ & Medium & 4 seasons $(1-12)$ & Morning/24h & Yes & No & Yes & No & No & No \\
\hline & Bs & 2005 & 16 & 900 & 1.5 & $50-75$ & Yes & 2011 & $5-6$ & $100-150$ & Medium & 4 seasons $(1-12)$ & Morning & Yes & No & Yes & Yes & Yes & No \\
\hline & $\mathrm{Br}$, Bs & 2004 & 15 & 120 & 1.2 & 31 & No & - & - & - & - & - & - & - & - & - & - & - & - \\
\hline & $\mathrm{Br}, \mathrm{Bs}$ & 2005 & - & 1500 & 1.3 & 40 & Yes & 2008 & 3-5 & 100 & High & 4 seasons $(1-12)$ & Morning & Yes & No & Yes & Yes & Yes & No \\
\hline & $\mathrm{Br}$ Bs & 2010 & 19 & 350 & 1.4 & 70 & Yes & 2013 & 1 & 100 & Medium & Summer (5-10) & $24 \mathrm{~h}$ & No & No & No & Yes & Yes & No \\
\hline
\end{tabular}

Tu: tuna; Br: sea bream; Bs: sea bass; Me: meagre.

\# Pooled data from three facilities. 
ship between the presence of ABT (in terms of density and size of the aggregated individuals) and farming activity (i.e. number of cages, fish production, farm depth and distance to shore) were examined through lineal regressions. The magnitude of these potential interactions was evaluated and discussed according to the results obtained from the questionnaires and existing literature.

\section{Results}

Replies to the questionnaire were obtained from a total of 29 fish farms that mostly reared tuna, sea bream, sea bass and meagre in open-sea cages (Table 1 ). Tuna farms had a smaller number of cages (less than 20 pens) compared to facilities that reared other species (up to 68 net-pens for sea bream and sea bass), however, annual fish production was similar for both cultures (500-2500 tonnes/year) (Table 1, Fig. 2). Most of the fish farms are located at water depths of between $20 \mathrm{~m}$ and $70 \mathrm{~m}$, and up to one kilometre offshore. However, there were differences in the sea bream and sea bass farm facilities between different countries and localities (Table 1, Fig. 2). Farm-aggregated ABT were reported from 28 fish farms (>95\% of total farms), which represented a high frequency of occurrence. The reported ABT aggregations formed small groups of around 10 individuals or less in case of sea bream, sea bass and meagre farms, but comprised hundreds of aggregated individuals around tuna farms (Table 1, Fig. 2). In all cases, the weight of wild ABT individuals recorded from the farms ranged from $50 \mathrm{~kg}$ to $600 \mathrm{~kg}$, regardless of the fish species cultured (Table 1, Fig. 2). The first sightings of wild ABT differed among fish farms, which might be due to changes in working staff at different facilities, although it in most cases ABT was first reported to be present around the farms in early 2000. Overall, aggregated wild ABT are commonly observed throughout the whole year, although more frequent and larger groups are generally reported during the summer months or warmer seasons (from May to October). Moreover, the daily presence of ABT was reported to occur over the whole $24 \mathrm{~h}$ day period, but was especially noted to occur in the vicinity of fish farms during the morning hours when farm operational activities are higher; apparently the wild ABT exhibited curiosity for the presence of divers and boats (Table 1).

The survey results also indicated that staff from different Mediterranean fish farms reported that ABT interacts with fish cages in different ways (Table 1 ). For example, it was observed that ABT not only forages on accidental fish discards (e.g. Fig. 1), but also on the surplus feed fish (herring, sardine and mixed pelagic fish) that are fed to the caged tuna or on the small pelagic fish such as herring ( $S$. aurita) or bogue (B. boops) entangled in the pen net. However, when ABT feed on wild small pelagic fish aggregated around mariculture cages, they sometimes cause mortalities to the reared fish as a result of the stress endured; this mainly happens in the case of sea bass. Less common were reports that ABT is able to break into mariculture cages in search of food and consequently not only affects the fish rearing operations, but also provoke escape events of reared fish, and therefore, generates economic losses to the farmers.

Given the findings from the survey, there is an urgent and important need to improve knowledge about ABT behaviour, especially since the increasingly common and frequent aggregations of wild ABT around Mediterranean fish farm facilities can produce negative interactions with aquaculture. For example, in Malta, Croatia and Turkey, aggregations of ABT in the vicinity of tuna farms have become so common that amateur and professional fishermen regularly use the areas surrounding the farm cages as wild ABT fishing grounds. In Malta, individuals of wild ABT caught by hook and line sometimes break the fishing line and end up swimming free but retain the hook and a considerable length of line trailing from their mouth. If the tuna individual remains swimming in the vicinity of a fish farm, the line may get snagged against a cage or one of its mooring lines and the fish dies after a while if it does not break free. This leads to a slowly decomposing fish carcass in the vicinity of the fish farm. In the case of Spain and Italy, but also in Turkey, it is more often to observe recreational anglers and spear-gun fishermen in the vicinity of fish farms looking for big pelagic fish, such as ABT, but no negative interaction between fishing and farming activity have been reported.

\section{Discussion}

For farming purposes, wild-caught ABT are transferred to towed cages, and transported to the farm site by tugboats, after which they are moved again into on-growing cages to which they adapt very quickly (Ottolenghi, 2008; Mylonas et al., 2010). However, it is known that, occasionally, densities of $A B T$ in the fattening cages exceed the quota established by the ICCAT, and therefore some individuals must be intentionally released to the marine environment to comply with the regulations. In addition, some wild ABT may be attracted to a fish farm because of its FAD effect. Indeed, some interviewed farmers reported a remarkable increase of ABT aggregations since the establishment of quota regulations. Individuals which would have inhabited an on-growing cage for some time may have their migratory behaviour modified, given that they show some affinity to the fish farms by remaining aggregated there or visit the surrounding facilities. Sarà et al. (2007) suggested that tuna behaviour can be altered by anthropogenic disturbances, such as boat noise, which can modify swimming and schooling patterns, thereby affecting their natural migratory behaviour, including migration to spawning and feeding grounds. However, based on daily observations by the fish farm divers, the wild $A B T$ aggregated around fish farms are recorded throughout the year, except during harvesting time (January to February) and during the spawning period (June) of the species. It has been noted that the presence of tuna blood in surrounding waters, as well as vessel activity have a repelling effect on tuna aggregations ( $T$. Šegvić-Bubić, pers. comm.). Interestingly, during the spawning season, wild ABT are rarely seen, implying that breeding might be a trigger for migration to deeper waters, but they are again observed around cages in July.

A decrease in abundance of small pelagic fish around fish farms when ABT is aggregated was also observed (pers. com.), which might lead to a decrease in consumption of pellets, and therefore, reducing their "biofilter" effects. Moreover, since ABT feed on dead fish accidentally discarded from cages, this highlights the high adaptability and flexibility of the species to feed on new resources; this is similar to adaptation to feeding on feed-fish when in captivity. The constant feed availability at fish farm sites leads to behavioural changes in the tuna, which could lead to potential modifications on schooling behaviour, a key strategy for gregarious species. Consequently, an alteration in schooling behaviour could affect the tuna's homing accuracy to spawning and feeding grounds during migration (Sarà et al., 2007), potentially resulting in new coastal migratory routes or resident populations, at least at a local or regional scale. In as much, there is a need for research that should be directed towards understanding the extent of the influence of offshore fish farms on the biology and ecology of this very important natural marine resource.

Floating objects, or FADs, are commonly used by Mediterranean fishermen to capture tuna species that are attracted to such drifting objects (e.g. D’Anna et al., 1999; Deudero et al., 1999). However, it has been suggested that FADs can act as "ecological traps" for tuna species (Hallier and Gaertner, 2008). Ecological traps may form when artificial habitats that have ecological cues which wild 

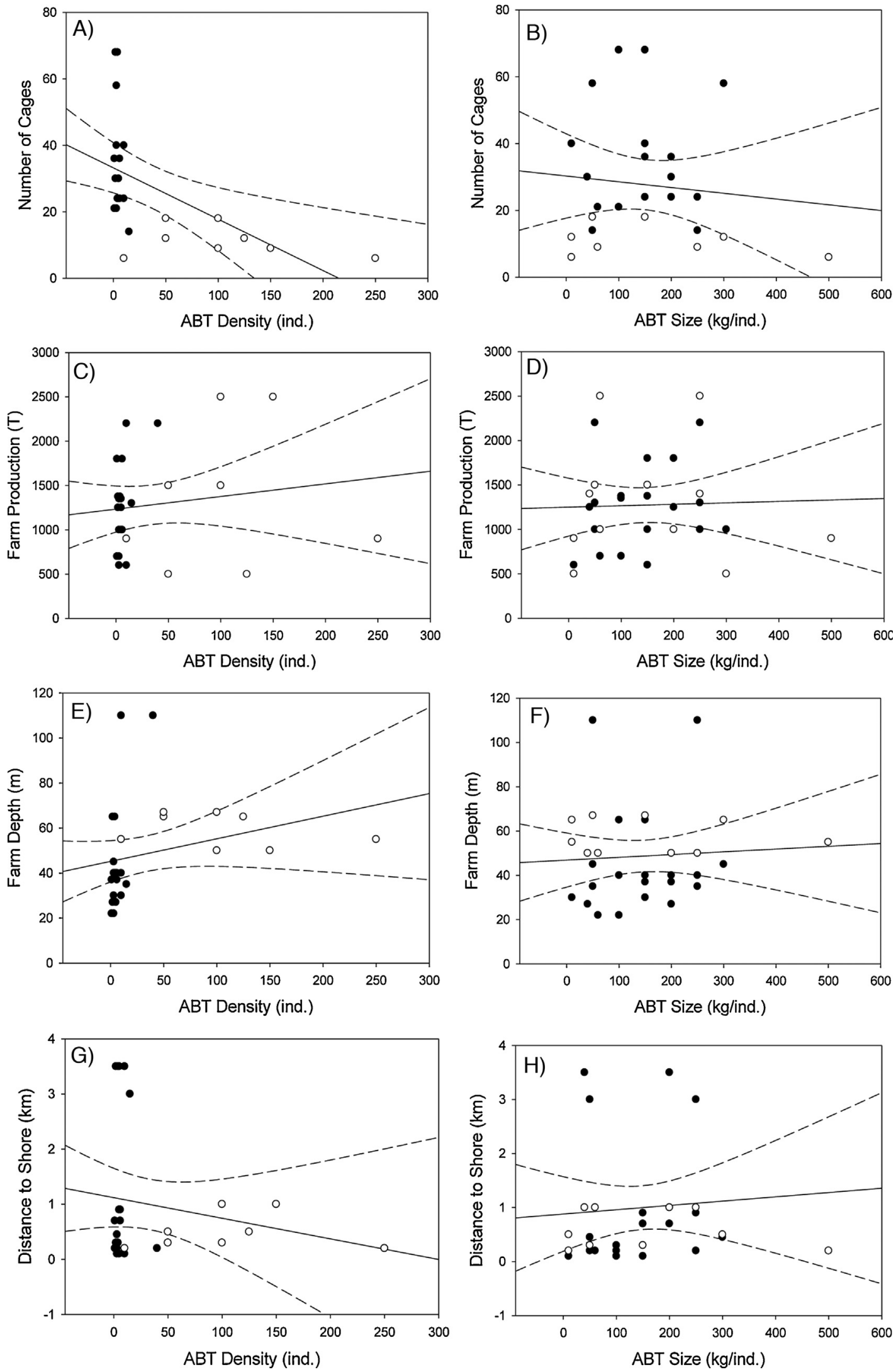

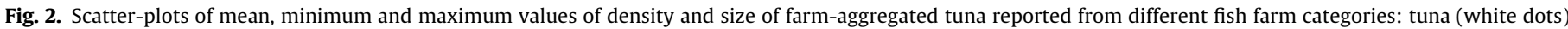
and other fish species, namely sea bream, sea bass, and meagre (black dots). Solid line: linear regression; dashed line: confidence interval (95\%). 
animals recognize in preferred habitats, are introduced into natural settings (Battin, 2004; Hallier and Gaertner, 2008). Typically, the existence of an ecological trap has been thought of as requiring negative behavioural or physiological effects that reduce the survival or reproductive capacity of a population (Battin, 2004; Robertson and Hutto, 2006), and lead to significant changes in migratory direction and displacement rates (Hallier and Gaertner, 2008). Therefore, such observations support our hypothesis that Mediterranean fish farms may act not only as a superstimulus, misleading farm-aggregated ABT into making inappropriate habitat selection, but also serve as ecological traps (Dempster et al., 2009). Even in the absence of any direct negative effects when in the vicinity of offshore fish cages, the sheer continuous presence of ABT individuals around fish farms, and the potential increase in the size of tuna aggregates, increases their vulnerability to capture and thus creates circumstances for the formation of an ecological trap, particularly if fishing interacts heavily with aquaculture sites. However, further studies are required to investigate the longterm effect of fish farms on the entire life cycle of ABT, as well as assessing the accuracy of reporting captures and of traditional population estimates based on fisheries-dependent data. To deter the ABT aggregating around fish farms, it may be useful to use powerful underwater noise-generating devices, called Acoustic Deterrent Devices (ADDs), which would frighten the tuna away from the fish farms by causing discomfort. However, such devices might also frighten marine mammals, especially cetaceans (whales, dolphins and porpoise) from their habitat areas if these happen to be in the vicinity of the fish farms, and may also interfere with the hearing of seals and other marine mammals; therefore before deployment, such secondary effects must be carefully assessed (Gordon and Northridge, 2002).

The combination of measures to regulate farming activities and enhance recovery of the ABT stock, as well as the Catch Documentation Scheme, will help monitor the numbers caught and traded (Ottolenghi, 2008). The tuna farming industry should consider the need to devise a better solution for determining the size and age composition of captured fish destined for farming operation, since a significant component of the tuna captured and transferred to cages is undersized or just within the legal minimum landing weight set by ICCAT (Relini, 2003). Since this leads to the established quotas of captured individuals being exceeded, the surplus individuals have to be released from the cages. The present lack of biometric information from the captured-based aquaculture sector during past stages makes stock assessment, management and conservation of the ABT resource rather difficult (Ottolenghi, 2008). Furthermore, there is great interest in establishing a sustainable tuna farming industry. This necessitates the development of specific technologies for tuna aquaculture that will not only rely on captured individuals from the wild, as practiced today (Mylonas et al., 2010), but on juveniles hatched in captivity. A 'true' tuna aquaculture industry that is independent of capture fisheries, controlling all the stages of the life cycle and with cages placed in off-shores locations, would greatly improve the current situation, but concerns regarding fishing pressure on small pelagic fish to feed the farmed tuna will remain (Relini, 2003).

To sum up, large pelagic fish of economic importance such as ABT have been detected around fish farms. However, fish farmers believe that individuals of ABT take up permanent residence in the vicinity of fish cages, especially those with sea bass, sea bream and tuna, and that this phenomenon has been noted to increase as of 2011. This may be explained because such individuals would have been previously captured for fattening and later released following exceedance of the quota. Consequently, they are partially adapted to the shelter of the artificial habitat, where they find a high abundance of food (dead fish and small pelagic fish). Therefore, such ABT individuals may have also modified their migratory behaviour. It seems that such individuals do not migrate out of the Mediterranean Sea during the winter, and remain in the vicinity of a fish farm throughout the year. This aggregation behaviour may have indirect effects, some of which may be adverse for the species. First, ABT may be caught easily by sport or professional fishermen, increasing their vulnerability. Second, ABT may stress farmed fish, leading to economic losses to farmers. However, ABT also seems to scare away other predatory fish, such as bluefish (P. saltatrix), which are usually abundant around fish farms, hence reducing the negative effect of such species on fish farming. In doing so, the ABT may be altering the dynamics of local wild fish populations. However, they could be indirectly increasing the amount of uneaten feed and fish faeces coming from marine sea cages by feeding on or scaring small pelagic wild farm-aggregated fish that usually consume them. Because of the high relevance of ABT conservation, it is necessary to investigate this topic further and determine the positive and negative effects for fish farming and ABT conservation.

\section{Acknowledgements}

We are very grateful to the anonymous collaborators from fish farms throughout the Mediterranean basin for sharing their knowledge with us. We also want to thank the scientific colleagues for their help with the distribution of questionnaires and Daniele Bracciaferri for sharing his pictures (e.g. Fig. 1).

\section{References}

Akyol, O., Ertosluk, O., 2010. Fishing near sea-cage farms along the coast of the Turkish Aegean Sea. J. Appl. Ichthyol. 26, 11-15.

Arechavala-Lopez, P., Izquierdo-Gomez, D., Sanchez-Jerez, P., 2014b. First report of a swordfish (Xiphias gladius Linnaeus, 1758) beneath open-sea farming cages in the Western Mediterranean Sea. Mediterr. Mar. Sci. 15, 72-73.

Arechavala-Lopez, P., Izquierdo-Gomez, D., Uglem, I., Sanchez-Jerez, P., 2014a. Aggregations of bluefish Pomatomus saltatrix (L.) at Mediterranean coastal fish farms: seasonal changes, daily patterns and influence of farming activity. Environ. Biol. Fish, http://dx.doi.org/10.1007/s10641-014-0280-5 (in press).

Bacher, K., Gordoa, A., Sagué, O., 2012. Spatial and temporal extension of wild fish aggregations at Sparus aurata and Thunnus thynnus farms in the north-western Mediterranean. Aquacult. Environ. Interact. 2, 239-252.

Bacher, K., Gordoa, A., Sagué, O., 2013. Feeding activity strongly affects the variability of wild fish aggregations within fish farms: a sea bream farm as a case study. Aquacult. Res., http://dx.doi.org/10.1111/are.12199 (in press).

Bard, F.X., Bach, P., Josse, E., 1998. Habitat et écophysiologie des thons: Quoi de neuf depuis 15 ans? Coll. Vol. Sci. Pap. ICCAT 50, 319-342

Battin, J., 2004. When good animals love bad habitats: ecological traps and conservation of animal populations. Conserv. Biol. 18 (6), 1482-1491.

Block, B.A., Teo, S.L.H., Walli, A., Boustany, A., Stokesbury, M.J.W., Farwell, C.J., Weng, K.C., Dewar, H., Williams, T.D., 2005. Electronic tagging and population structure of Atlantic Bluefin Tuna. Nature 434, 1121-1127.

D’Anna, G., Badalamenti, F., Riggio, S., 1999. Traditional and experimental floating fish aggregating devices in the Gulf of Castellamare (NW Sicily): results from catches and visual observations. Sci. Mar. 63 (3-4), 209-218.

Dempster, T., Sanchez-Jerez, P., Bayle-Sempere, J.T., Giménez-Casalduero, F., Valle, C., 2002. Attraction of wild fish to sea-cage fish farms in the south-western Mediterranean Sea: spatial and short-term temporal variability. Mar. Ecol. Prog. Ser. 242, 237-252

Dempster, T., Tanquet, M., 2004. Analysis of the literature on fish aggregation devices (FAD) research: gaps in current knowledge and future research directions for studies of FAD-associated fish. Rev. Fish Biol. Fish. 14, 21-42.

Dempster, T., Uglem, I., Sanchez-Jerez, P., Fernandez-Jover, D., Bayle-Sempere, J. Nilsen, R., Bjørn, P.A., 2009. Coastal salmon farms attract large and persistent aggregations of wild fish: an ecosystem effect. Mar. Ecol. Prog. Ser. 385, 1-14.

Deudero, S., Merella, P., Morales-Nin, B., Massuti, E., Alemany, F., 1999. Fish communities associated with FADs. Sci. Mar. 63, 199-207.

Díaz-López, B., Bernal-Shirai, J.A., 2007. Bottlenose dolphin (Tursiops truncatus) presence and incidental capture in a marine fish farm on the north-eastern coast of Sardinia (Italy). J. Mar. Biol. Assoc. U.K. 87, 113-117.

Fernandez-Jover, D., Sanchez-Jerez, P., Bayle-Sempere, J.T., Valle, C., Dempster, T., 2008. Seasonal patterns and diets of wild fish assemblages associated with Mediterranean coastal fish farms. ICES J. Mar. Sci. 65, 1153-1160.

Fromentin, J.M., Fonteneau, A., 2001. Fishing effects and life history traits: a casestudy comparing tropical versus temperate tunas. Fish. Res. 53, 133-150.

Fromentin, J.M., Powers, J.E., 2005. Atlantic Bluefin Tuna: population dynamics, ecology, fisheries and management. Fish Fish. 6, 281-306. 
Gordon, J., Northridge, S., 2002. Potential impacts of acoustic deterrent devices on Scottish marine wildlife. In: Scottish Natural Heritage Commissioned Report F01AA404. Final Report (63 pp.).

Güçlüsoy, H., Savas, Y., 2003. Interaction between monk seals Monachus monachus (Hermann, 1779) and marine fish farms in the Turkish Aegean and management of the problem. Aquacult. Res. 34, 777-783.

Hallier, J.P., Gaertner, D., 2008. Drifting fish aggregation devices could act as an ecological trap for tropical tuna species. Mar. Ecol. Prog. Ser. 353, 255-264.

ICCAT, 2012. Report of the 2012 Atlantic Bluefin Tuna stock assessment session. In: Meeting Report of the Standing Committee on Research and Statistics (SCRS), International Commission for the conservation of Atlantic Tunas (ICCAT), October 2012, Madrid, Spain (Doc. Num. SCI-033/2012, $124 \mathrm{pp})$.

Kingsford, M.J., 1999. Fish attraction devices (FADs) and experimental designs. Sci. Mar. 63 (3-4), 181-190.

Mather, F.J., Mason, J.M., Jones, C.A., 1995. Historical document: life history and fisheries of Atlantic Bluefin Tuna. In: NOAA Tech Memo NMFS 370. U.S. Dept. of Commerce, National Oceanic and Atmospheric Administration, National Marine Fisheries Service.

Mylonas, C.C., de la Gándara, F., Correiro, A., Belmonte Ríos, A., 2010. Atlantic Bluefin Tuna (Thunnus Thynnus) farming and fattening in the Mediterranean Sea. Rev. Fish. Sci. 18 (3), 266-280.

Ottolenghi, F., 2008. Capture-based aquaculture of bluefin tuna. In: Lovatelli, A., Holthus, P.F (Eds.), Capture-based Aquaculture. Global Overview. FAO Fisheries Technical Paper No. 508. FAO, Rome, pp. 169-182.
Piroddi, Ch., Bearzi, G., Christensen, V., 2011. Marine open cage aquaculture in the eastern Mediterranean Sea: a new trophic resource for bottlenose dolphins. Mar. Ecol. Prog. Ser. 440, 255-266.

Relini, G., 2003. Fishery and aquaculture relationship in the Mediterranean: present and future. Mediterr. Mar. Sci. 4/2, 125-154.

Robertson, B.A., Hutto, R.L., 2006. A framework for understanding ecological traps and an evaluation of existing evidence. Ecology 87, 1075-1085.

Sanchez-Jerez, P., Fernandez-Jover, D., Bayle-Sempere, J., Valle, C., Dempster, T. Tuya, F., Juanes, F., 2008. Interactions between bluefish Pomatomus saltatrix (L.) and coastal sea-cage farms in the Mediterranean Sea. Aquaculture 282, 61-67.

Sanchez-Jerez, P., Fernández-Jover, D., Uglem, I., Arechavala-López, P., Dempster, T., Bayle-Sempere, J.T., Valle Pérez, C., Izquierdo, D., Bjørn, P.A., Nilsen, R., 2011. Coastal fish farms as fish aggregation devices (FADs). In: Bortone, S.A., Pereira Brandini, F., Fabi, G., Otake, S. (Eds.), Artificial Reefs in Fishery Management. CRC Press, Taylor \& Francis Group, Boca Raton, FL, pp. 187-208.

Sarà, G., Dean, J.M., D’Amato, D., Buscaino, G., Oliveri, A., Genovese, S., Ferro, S., Buffa G., Lo Martire, M., Mazzola, S., 2007. Effect of boat noise on the behaviour of bluefin tuna Thunnus thynnus in the Mediterranean Sea. Mar. Ecol. Prog. Ser. $331,243-253$.

Šegvić-Bubić, T., Grubišić, L., Tičina, V., Katavić, I., 2011. Temporal and spatial variability of pelagic wild fish assemblages around Atlantic Bluefin Tuna (Thunnus thynnus) farms in the eastern Adriatic Sea. J. Fish Biol. 78, 78-97. 